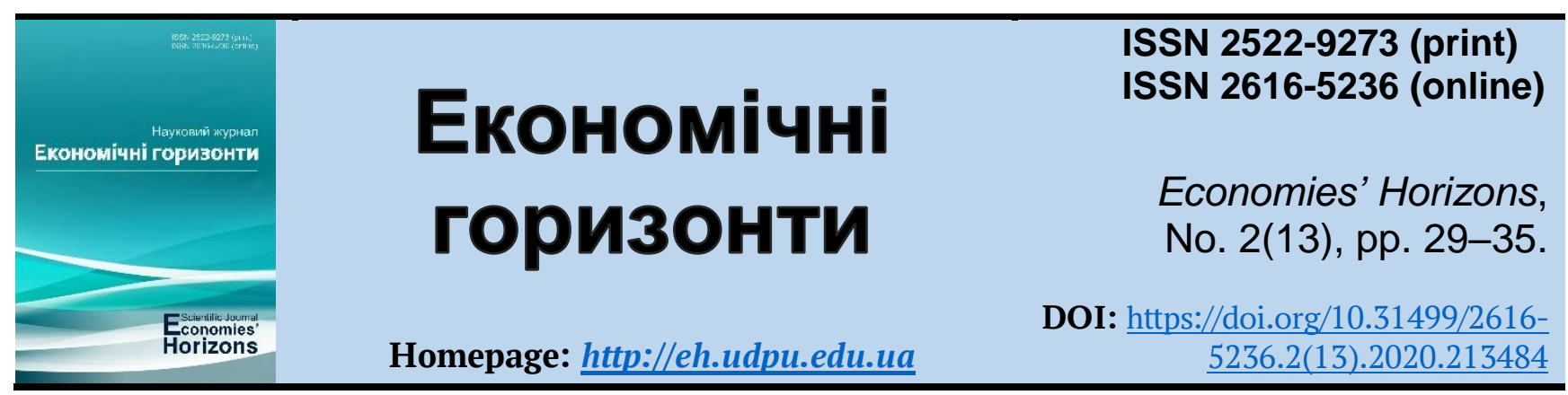

UDC 334.722.012.64:631(477)

\title{
Current trends in the development of small businesses in Ukrainian agriculture
}

\author{
Petro Yu. Kurmaiev ${ }^{1}$, Doc. Ec. Sc., Associate Professor \\ Paraskoviia T. Kolisnichenko², Cand. Ec. Sc.
}

Received: 4 May 2020

Accepted: 4 June 2020
Kurmaiev, P. Yu. and Kolisnichenko, P. T. (2020), "Current trends in the development of small businesses in Ukrainian agriculture", Economies' Horizons, no. 2(13), pp. 29-35. doi: https://doi.org/10.31499/2616-5236.2(13).2020.213484

Abstract. Purpose of the research. The aim of the article is to analyze the activities of small agricultural enterprises in Ukraine and identify the main obstacles to their development. Methodology. The following methods were used in the research process: generalization and comparative analysis. The authors used sources of statistical information and analytical reviews. The list of them is given in the list of references. Results. The article analyzes the main indicators that characterize the efficiency of small business in Ukraine. The role of small enterprises in the economy of developed countries is studied. It is noted that the impact of small business performance on gross domestic product (GDP) dynamics is different and depends on many factors - both historical and other, related, for example, to the structure of the economy, the culture of entrepreneurship. It is indicated that with the independence of our country, small business has developed rapidly, its share in the total number of businesses has grown. The main indicators that characterize the activity of small enterprises in agriculture of Ukraine are analyzed. The results of the study show a positive trend towards increasing the profitability of small businesses operating in agriculture in Ukraine. Practical meaning. The main obstacles to the development of small business in Ukraine have been identified. These include: low efficiency of legal regulation of economic relations, high levels of corruption and raiding. The authors notes that the acceleration of positive trends in small business development is possible provided that the level of favorable business environment in Ukraine is increased. Prospects for further research may be a mechanism for reconciling the interests of the subjects of the process of small business social responsibility.

Keywords: agriculture; small business; enterprise; profit; shadow economy.

JEL Classification: E2, L2, M2.

Number of references: 16; number of tables: 0; number of figures: 4; number of formulas: $\mathbf{0 .}$

\footnotetext{
${ }^{1}$ Pavlo Tychyna Uman State Pedagogical University; Professor at the Department of Finances, Accounting and Economic Security; ORCID ID: https://orcid.org/0000-0001-9464-0380; e-mail: petrol09@i.ua.

${ }^{2}$ Independent Researcher; ORCID ID: https://orcid.org/0000-0001-6730-1236; e-mail: ris@it-tim.net.
} 


\title{
Сучасні тенденції розвитку підприємств малого бізнесу у сільському господарстві України
}

\author{
Петро Юрійович Курмаєв ${ }^{1}$, д. е. н., доцент \\ Парасковія Тимофіївна Колісніченко ${ }^{2}$, к. е. н.
}

Стаття надійшла: 04.05.2020

Стаття прийнята: 04.06.2020
Kurmaiev P. Yu., Kolisnichenko P. T. Current trends in the development of small businesses in Ukrainian agriculture. Економічні горизонти. 2020. № 2(13). С. 2935. DOI: 10.31499/2616-5236.2(13).2020.213484

Анотація. Мета дослідження. Метою статті є аналіз діяльності малих сільськогосподарських підприємств в Україні та ідентифікація основних перешкод їх розвитку. Методологія. У процесі дослідження використано наступні методи: узагальнення та компаративного аналізу. Авторами використано джерела статистичної інформації та аналітичних оглядів, перелік яких наведено у списку літератури. Результати. У статті проаналізовано основні показники, які характеризують ефективність функціонування малого бізнесу в Україні. Досліджено роль малих підприємств в економіці розвинених країн. Зазначається, що вплив результатів діяльності підприємств малого бізнесу на динаміку валового внутрішнього продукту (ВВП) $є$ різний й залежить від багатьох чинників - як історичних, так й інших, пов'язаних, наприклад, із структурою економіки, культурою підприємництва. Вказується, що із здобуттям незалежності нашою країною, малий бізнес стрімко розвивався, зростала його частка у загальній кількості суб'єктів господарювання. Проаналізовано основні показники, які характеризують діяльність малих підприємств у сільському господарстві України. Результати дослідження засвідчують позитивну тенденцію до зростання прибутковості підприємств малого бізнесу, які функціонують у сільському господарстві в Україні. Практичне значення. Ідентифіковано основні перешкоди розвитку малого бізнесу в Україні. До них віднесено: низька ефективність нормативно-правового регулювання господарських відносин, високий рівень корупції та рейдерство. Авторами зазначено, що прискорення позитивних тенденцій розвитку малого бізнесу є можливим за умови підвищення рівня сприятливості підприємницького середовища в Україні. Перспективами подальщих досліджень можуть стати дослідження механізму узгодження інтересів суб’єктів процесу соціальної відповідальності малого бізнесу.

Ключові слова: сільське господарство; малий бізнес; підприємство; прибуток; тіньова економіка.

Кількість джерел: 16; кількість таблиць: 0; кількість рисунків: 4; кількість формул: 0.

\section{Introduction.}

Individual entrepreneurial activity has historically been the first form of business. Its evolution has led to the emergence of new organizational and legal forms, mechanisms of interaction with social institutions. The post-socialist transformation of Ukraine's economy has created the preconditions for the functioning of various forms of entrepreneurial activity, including small business. The urgency of small business development is determined by the important, sometimes decisive, role it can play in the country's economy.

\section{Literature review.}

The results of a study of various aspects of the functioning of small businesses are

\footnotetext{
1 Уманський держсавний педагогічний університет імені Павла Тичини; професор кафедри фінансів, обліку та економічної безпеки; ідентифікатор ORCID: https://orcid.org/0000-0001-9464-0380; e-mail: petrol09@i.ua.

${ }^{2}$ Незалежний дослідник; ідентифікатор ORCID: https://orcid.org/0000-0001-6730-1236; e-mail: ris@ittim.net.
} 
presented in the scientific work D. Storey (1994). The author analyzes in detail the life cycle of firms, identifies and systematizes the main factors influencing their development. Attention is paid to the financing of small companies and their interaction with the labor market. Interesting from a scientific point of view is the article of the team of authors (Dunne et al., 2016). The authors analyze the relationship between the degree of development of the institution of entrepreneurship leadership and the introduction of innovations. The results of the study showed that the leadership style of the entrepreneur and the organizational efficiency of his company create the preconditions for the production of innovations. Scientific work authored by M. Valos, F. Mavondo and M. Nyadzayo (2019) presents the results of the study about the impact of market orientation of the company on the efficiency of its operation. The results of a survey conducted by the authors showed that market orientation improves the financial performance of the company only if the brand is effective. Also, the article focuses on investing in branding and analysis of the competitive environment. A rather important issue of social responsibility of small business is considered in the article L. Spence (2016).

\section{Methods.}

The following methods were used in the research process: generalization (allowed to identify general trends in the development of agricultural enterprises) and comparative analysis (made it possible to compare economic indicators depending on the size of enterprises). The author used sources of statistical information and analytical reviews. The list of them is given in the list of references.

\section{Research objectives.}

The aim of the article is to analyze the activities of small agricultural enterprises in Ukraine and identify the main obstacles to their development.

\section{Results and discussions.}

Small businesses are an important part of the economies of many countries. Their impact on GDP dynamics is different and depends on many factors - both historical and other, related, for example, to the structure of the economy, the culture of entrepreneurship.

In economically developed countries, the small business sector occupies a stable position. For example, in 2018 in the United States the number of small businesses is 30.2 million units, which is $99.9 \%$ of all entities (Small Business Administration, 2018). The share of exports of small businesses amounted to $32.9 \%$ of the total. In general, $47.5 \%$ of all employees work in the economy in small business, and in such economic activities as "Accommodation and Catering”, "Construction”, "Wholesale”, "Real Estate”, “Arts, Entertainment and Sports" - there world more than 50\% of employees (Small Business Administration, 2018). During 2005-2019, 64\% of new jobs were created in small businesses (Small Business Administration, 2020). The average income of persons engaged in individual employment in their own incorporated companies amounted to \$50,347 (Small Business Administration, 2018).

Similar trends are observed in other countries. In OECD countries, small businesses are the main employers, employing up to $70 \%$ of employees, which provide up to $60 \%$ of value added (Organisation for Economic Co-operation and Development, 2017). Data analysis shows that the indicators of small business development in most post-socialist European countries (eg, Latvia, Lithuania, Estonia, Croatia, Bulgaria, Hungary, Poland) are comparable to the EU-15 (Organisation for Economic Co-operation and Development, 2017).

In Ukraine, the dynamics of the number of small enterprises during 1990-2017 was positive. Since gaining independence from our country, small business has developed rapidly, its share in the total number of businesses has grown. The data in Figure 1 show an increase during 2013-2018 in the share of small businesses due to large and medium entities. 


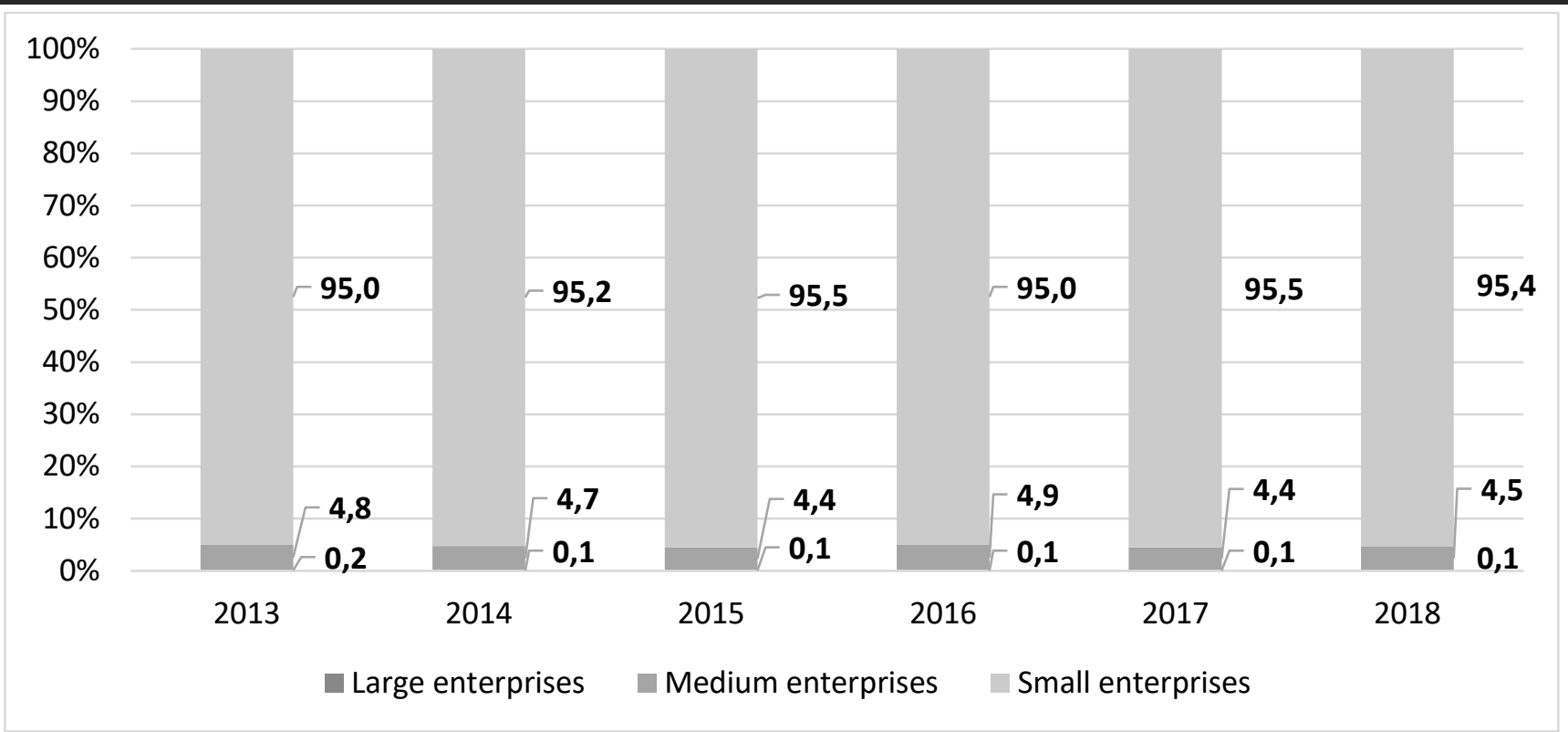

Fig. 1. The share of enterprises divided into large, medium and small enterprises, $\%$ Source: State Statistical Service of Ukraine (2020).

In $2017,14 \%$ of enterprises in the entire economy were located in the capital - Kyiv, and they employed $24 \%$ of the workforce. In addition, $11 \%$ of private entrepreneurs and $25 \%$ of the total number of legal entities were concentrated in Kyiv (Organisation for Economic Co-operation and Development, 2019).

The number of small enterprises registered in rural areas and their activities related to agriculture increased by $2.7 \%$ in $2013-2018$. The dynamics of growth in the number of economic entities in rural areas in Ukraine had similar indicators as in the United States, although the factors of influence, of course, were different. For example, in the United States, the growth rate of rural businesses in 20002018 was $7.2 \%$, particularly in 2013-2018 $2.2 \%$ (Wilmoth, 2019).

The share of employees in small businesses in Ukraine also tended to increase (Figure 2). The share of the small and medium enterprise sector as a whole increased during 2013-2018 by 5.8 percentage points.

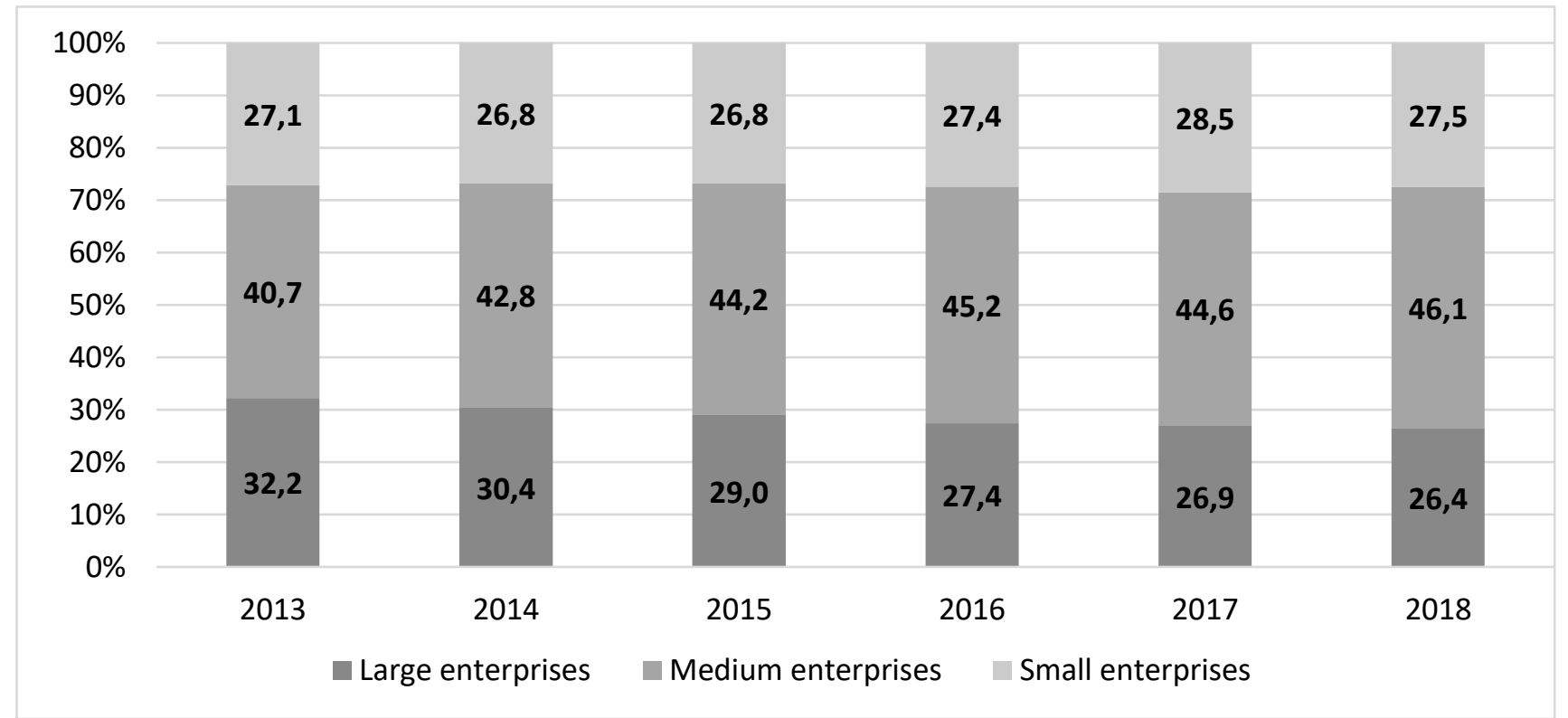

Fig. 2. The share of small, medium and large enterprises in terms of employment, \%

Source: State Statistical Service of Ukraine (2020). 
Analysis of the distribution of employees of small enterprises by type of economic activity showed the existence of the following trends. The share of employees in small enterprises increased in all major economic activities, except for "Wholesale and Retail Trade".

The largest share of employees in small businesses is working in construction (58.1\%), temporary accommodation (46.1\%), provision of information and communication services (41.5\%), agriculture (38.7\%).

The results of the analysis of employment indicators in agriculture during 20132018 show a decrease of $6 \%$ in the number of employees of small enterprises. However, the rate of decline in the number of employees of small enterprises is lower than in medium and large (Figure 3).

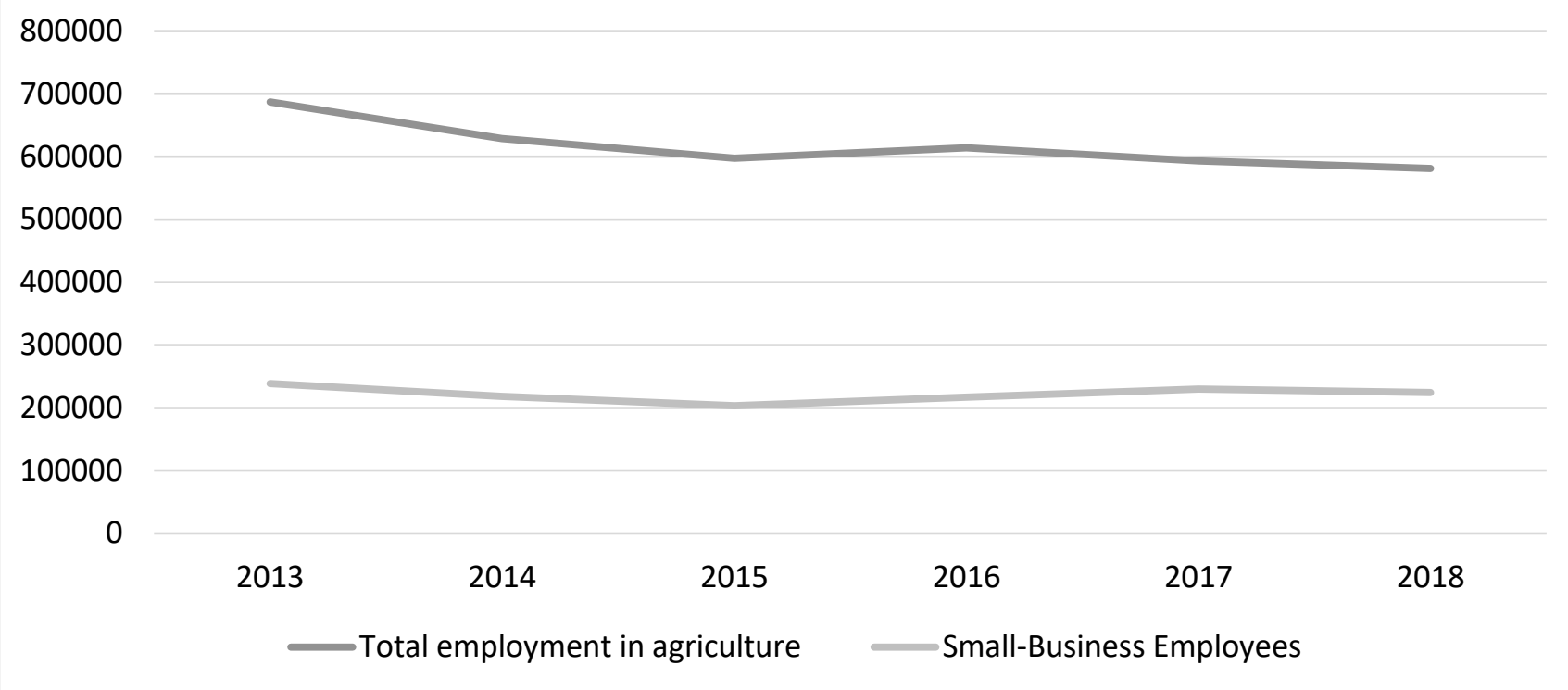

Fig. 3. Dynamics of employment in agricultural enterprises, persons

Source: State Statistical Service of Ukraine (2020).

The share of small enterprises in sales in 2013-2017 increased by $2.6 \%$. The most significant growth rates of the share of small business were characterized by such types of economic activity as: construction - up to $49.8 \%$ of the total sales by business entities (increase was 10.3 percentage points); agriculture - up to $39 \%$ (increase of 8.7 percentage points); information and telecommunication activity - up to $29.5 \%$ (increase of 8.4 percentage points). Given the importance of solving the problem of food security, positive, in our opinion, is the growth of the share of sales of small businesses in agriculture of more than 4 times.

In our opinion, the share of small business in sales in Ukraine is slightly higher, as it is necessary to take into account the size of the shadow sector of the economy.

Thus, according to the calculations of the Ministry of Economic Development, the level of the shadow economy in 2017 amounted to $31 \%$ of official GDP (Ministry of Economic Development, Trade and Agriculture, 2020). In 2018-2019, the indicator of the shadow sector in the FEA “Agriculture, Forestry and Fisheries" increased significantly.

According to experts (Ministry of Economic Development, Trade and Agriculture, 2020), the negative trend of changing the level of the shadow economy in foreign trade " $\mathrm{Ag}$ riculture, Forestry and Fisheries" was formed as a result of rising production costs at high cost of lending to agricultural enterprises (objects with high credit risks) (Ministry of Economic Development, Trade and Agriculture, 2020).

The percentage of the total number of profitable small businesses in agriculture is, in general, comparable to medium and large businesses. The percentage of profitable small 
businesses is growing steadily during 20132015 (Figure 4). In 2018, this figure was

$86.1 \%$, which is 6.1 percentage points more than in 2013.

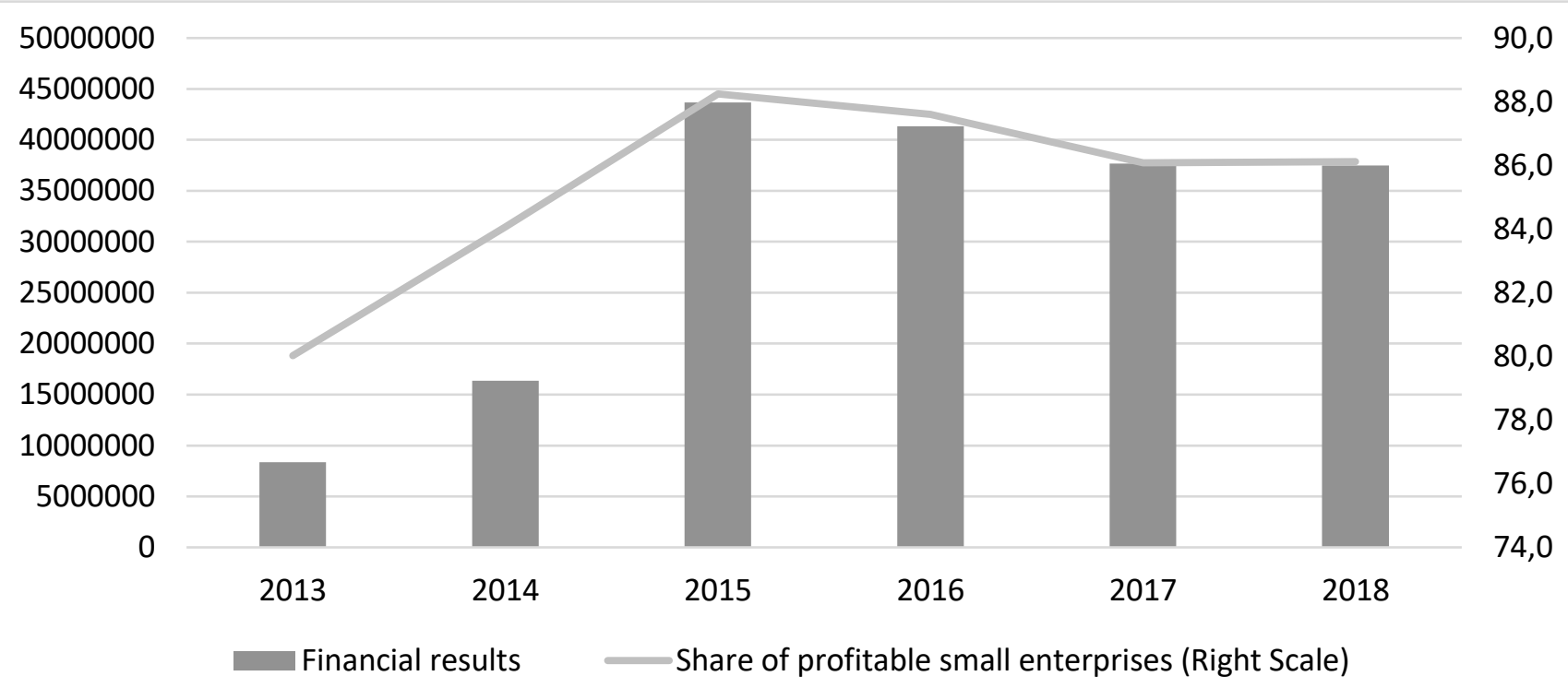

Fig. 4. Financial results before tax (thousand UAH) and the share of profitable small enterprises in agriculture (\%) for 2013-2018

Source: State Statistical Service of Ukraine (2020).

The data of Figure 4 show a positive trend to reduce the losses of small businesses engaged in agricultural activities in Ukraine. Thus, during 2013-2018, the amount of net profit increased more than 5 times and amounted to UAH 21.3 billion.

The amount of losses of small enterprises in other economic activities increased. Among the leaders in terms of growth in the amount of losses, it is appropriate to name the enterprises of the following foreign trade activities: "Real estate activities" (increase in losses by UAH 9.7 billion), "Industry" (increase in losses by UAH 3.9 billion), "Professional, scientific and technical activities" (increase in losses by UAH 2.8 billion).

In some cases, the loss of small businesses is an attempt to minimize tax payments. At the same time, in our opinion, the main obstacle to the development of small businesses is the unfavorable business environment. For example, in the ranking of doing business in Ukraine in 2018, Ukraine ranked only 76th among 190 countries (World Bank Group, 2018). The value of the Corruption Perceptions Index was 32 points (120th place among 180 countries).
Among its neighbors, Ukraine was able to bypass only the Russian Federation (28 points, 138th place). Instead, the rest have higher scores: Poland - 60, Slovakia - 50, Romania - 47, Hungary - 46, Belarus - 44, Moldova - 33 points (Transparency International, 2018).

\section{Conclusions.}

The analysis of small business enterprises in agriculture showed the presence of positive trends. The use of opportunities for rapid business differentiation, sometimes minimizing tax payments, has increased the role of small business in the economy of our country. Acceleration of positive trends in small business development is possible provided that the level of favorable business environment in Ukraine increases. In this context, the problem of optimizing the regulatory framework (Kurmaiev, 2009), reducing corruption and related raiding needs to be addressed as a matter of priority. For example, according to the survey (Marchuk, 2019), 75\% of agricultural respondents rated the level of threat of a raider attack as high and medium. The victims of raiders are mainly farms with between 1,000 and 3,000 hectares of land in use (The Verkhovna Rada 
of Ukraine, 2017).

Effective counteraction to the abovementioned criminal acts will contribute to the improvement of the business environment and, ultimately, the development of small business in Ukraine. Prospects for further research may be a mechanism for reconciling the interests of the subjects of the process of small business social responsibility.

\section{References}

Dunne, T. C., Aaron, J. R., McDowell, W. C., Urban, D. J. and Geho, P. R. (2016), “The impact of leadership on small business innovativeness", Journal of Business Research, vol.69, no. 11, pp. 4876-4881, doi: https://doi.org/10.1016/i.jbusres.2016.04.046

Kurmaiev, P. Yu. (2009), "Analysis of regulatory and legal support of the process of socio-economic development management at the regional level”, Economic Space, no. 24, pp. 38-44.

Marchuk, D. (2019), “Agrarians against raiders: on whose side is the government?”, Economic Truth, available at: https://www.epravda.com.ua/columns/2019/03/20/646220 (Accessed 20 April 2020).

Ministry of Economic Development, Trade and Agriculture of Ukraine (2020), Zahalni tendentsii tinovoi ekonomiky v Ukraini v 2019 rotsi [General trends of the shadow economy in Ukraine in 2019], Ministry of Economic Development and Trade of Ukraine, Kyiv, Ukraine, 8 p. available at: https://www.me.gov.ua/Documents/Download?id=e5906118-6639-4dde-851b-2d9cd318e803 (Accessed 20 April 2020).

Organisation for Economic Co-operation and Development (2017), Enhancing the Contributions of SMEs in a Global and Digitalised Economy, OECD, Paris, France, 24 p. available at: https://www.oecd.org/industry/C-MIN-2017-8-EN.pdf (Accessed 20 April 2020).

Organisation for Economic Co-operation and Development (2019), Zbirnyk statystyky pidpryiemnytstva $v$ Ukraini: 2018 [Collection of business statistics in Ukraine: 2018], OECD, Paris, France, 42 p. available at: https://www.oecd.org/eurasia/competitiveness-programme/eastern-partners/Compendium-EntrepriseStatistics-Ukraine-2018-Ukrainian.pdf (Accessed 20 April 2020).

Small Business Administration (2018), “United States Small Business Profile, 2018”, available at: https://www.sba.gov/sites/default/files/advocacy/2018-Small-Business-Profiles-US.pdf （Accessed 20 April 2020).

Small Business Administration (2020), "Economic bulletin”, available at: https://cdn.advocacy.sba.gov/wpcontent/uploads/2020/04/30103025/April-2020-Econ-Bulletin.pdf (Accessed 20 April 2020).

Spence, L. J. (2016), “Small Business Social responsibility: expanding core CSR theory”, Business \& Society, vol. 55, no. 1, pp. 23-55, doi: https://doi.org/10.1177/0007650314523256

State Statistics Service of Ukraine (2020), "Economic Statistics. Economic activity. Activities of enterprises", available at: http://www.ukrstat.gov.ua/operativ/menu/menu u/sze 20.htm (Accessed 20 April 2020).

Storey, D. J. (1994), Understanding the small business sector, Routledge, London, UK, 280 p. doi: https://doi.org/10.4324/9781315544335

The Verkhovna Rada of Ukraine (2017), "Speech by O. B. Bakumenko at the meeting of the Committee on Agrarian Policy and Land Relations on September 5, 2017", available at: http://komagropolit.rada.gov.ua/fsview/73177.html (Accessed 20 April 2020).

Transparency International (2018), “Corruption Perceptions Index - 2018”, available at: https://tiukraine.org/research/indeks-spryinyattya-koruptsiyi-2018/ (Accessed 20 April 2020).

Valos, M. J., Mavondo, F. T. and Nyadzayo, M. W. (2019), "How do alternative strategic orientations influence social media performance?”, Journal of Strategic Marketing, vol. 27, no. 1, pp.1-20, doi: https://doi.org/10.1080/0965254X.2017.1384039

Wilmoth, D. (2019), "Growth in number of rural establishments”, available at: https://cdn.advocacy.sba.gov/wpcontent/uploads/2020/02/04111621/Rural-Business-Growth-Fact-Sheet1.pdf (Accessed 20 April 2020).

World Bank Group (2018), Doing Business 2018. Reforming to create jobs, The World Bank, Washington, USA, 303 p. available at: https://www.doingbusiness.org/content/dam/doingBusiness/media/AnnualReports/English/DB2018-Full-Report.pdf (Accessed 20 April 2020).

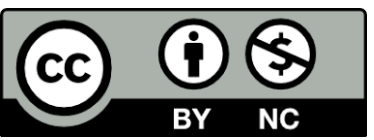

Цей твір ліцензовано на умовах Ліцензії Creative Commons «/з Зазначенням Авторства - Некомериійна 4.0 Міжнародна» (CC BY-NC 4.0). This is an open access journal and all published articles are licensed under a Creative Commons "Attribution-NonCommercial 4.0 International" (CC BY-NC 4.0). 